\title{
Taraxerol protects the human hepatic L02 cells from hydrogen peroxide-induced apoptosis
}

Xiang-Yang Yao and Qin Bai

School of Food and Biology Engineering, Bengbu University, Bengbu 233030, China.

\begin{tabular}{|c|c|}
\hline \multicolumn{2}{|l|}{ Article Info } \\
\hline Received: & 6 January 2017 \\
\hline Accepted: & 7 March 2017 \\
\hline Available Online: & 20 April 2017 \\
\hline \multicolumn{2}{|c|}{ DOI: 10.3329/bjp.v12i2.30985 } \\
\hline \multicolumn{2}{|c|}{$\begin{array}{l}\text { Cite this article: } \\
\text { Yao XY, Bai Q. Taraxerol protects the } \\
\text { human hepatic L02 cells from hydro- } \\
\text { gen peroxide-induced apoptosis } \\
\text { Bangladesh J Pharmacol. 2017; 12: } 133 \\
-39 \text {. }\end{array}$} \\
\hline
\end{tabular}

\section{Introduction}

Hydrogen peroxide $\left(\mathrm{H}_{2} \mathrm{O}_{2}\right)$ is an important member of the reactive oxygen species (ROS) family of molecules that have been investigated in recent years (Brewer et al., 2015). Low levels of $\mathrm{H}_{2} \mathrm{O}_{2}$ are required for many biochemical processes, such as cell differentiation, immunity, antimicrobial infection (Veal and Day, 2011). However, excessive increase of $\mathrm{H}_{2} \mathrm{O}_{2}$ can lead to mitochondrial damage, lipid peroxidation, cytokine release, and cell death, which are involved in cancers, diabetes, rheumatisms and various neurological disorders (Gough and Cotter, 2011). Liver damage is often accompanied by apoptosis of liver cells (Guicciardi and Gores, 2010). Therefore, anti-oxidants may reverse oxidative stress-induced cell death in liver cells.

Taraxerol is a triterpenoid isolated from many medicinal plants including Mangifera indica, Taraxacum japonicum, Achillea millefolium and Acrocarpus andfraxinifolius (Sharma and Zafar, 2015). Taraxerol is also known to exhibit anti-inflammatory and anticancer activity (Tsao et al., 2008; Takasaki et al., 1999; Setzer et al., 2000; Jang et al., 2004). We have also reported that taraxerol significantly inhibited LPS- induced production of pro-inflammatory mediators by preventing the activation of TAK1, Akt and NF-kB (Yao et al., 2013). Taraxerol has an antidiabetic effect. It can be used as a PI3K dependent dual activator of glucose transport and glycogen synthesis and effectively restored dexamethasone-induced desensitization via restoration of PI3K and GLUT4 expression (Sangeetha et al., 2013; Sangeetha et al., 2010). However, cytoprotective effect and its mechanism of taraxerol on hepatocytes are unclear. In this study, we assessed taraxerol on $\mathrm{H}_{2} \mathrm{O}_{2-}$ induced apoptotic effect in L02 cells, and determined the activation of caspases-3, PARP, Bcl-2, Bax and MAPK.

\section{Materials and Methods \\ Chemicals}

Taraxerol (99\% purity analyzed by HPLC), 3-[4,5dimethylthiazol-2-yl]-2,5- diphenyltetrazolium bromide (MTT) were purchased from Sigma Chemical Co. (USA). Lactate dehydrogenase (LDH) assay kit was obtained from Nanjing Jiancheng Bioengineering Institute (China). The antibodies to Bcl-2, Bax, cleaved- 
caspase-3, PARP and polyclonal antibodies to p38, JNK/SAPK, and phospho-specific antibodies against JNK (Thr183/Tyr185), p38, U0126, SB203580, SP600125 were purchased from Cell Signaling Technology (USA). GAPDH antibody was from Bioworld Biotechnology (China).

\section{Cell culture and cell treatment}

The normal human hepatic cell strain, L02 obtained from Institute of Biochemistry and Cell Biology, the Chinese Academy of Sciences (China), was cultured in Dulbecco's modified Eagle's medium (DMEM) (Hyclone) supplemented with $10 \%$ fetal bovine serum (FBS) (Hyclone), $100 \mathrm{U} / \mathrm{mL}$ penicillin, and $100 \mu \mathrm{g} / \mathrm{mL}$ streptomycin at $37^{\circ} \mathrm{C}$ in a $5 \% \mathrm{CO}_{2}$ humidified environment. Taraxerol was dissolved in DMSO to make a stock of $100 \mathrm{mM}$ and further diluted to final concentrations of $20-200 \mu \mathrm{M}$ with a serum-free culture medium.

\section{Cell viability and LDH assay}

L02 cells were seeded into 96 -well plates ( $10^{5}$ cells/well) for 12 hours, followed by treatment with various concentrations of $\mathrm{H}_{2} \mathrm{O}_{2}$ or taraxerol. Cell viability was determined using MTT assay. The absorbance was measured at $570 \mathrm{~nm}$. The LDH levels in the medium were measured with the use of commercial kits according to the manufacturer's protocols after each treatment. The absorbance at $420 \mathrm{~nm}$ was recorded for the calculation of LDH activity under Mutiskan Go (Thermo, INC).

\section{Flow cytometric analysis}

The extent of apoptosis was measured through annexin V-FITC/PI apoptosis detection kit (Nanjing Keygen Biotech, KGA108) according to the manufacture's instruction. Cells were washed twice with PBS, gently resuspended in binding buffer and incubated with annexin-V-FITC and PI in the dark for $10 \mathrm{~min}$ and detected by flow cytometry (BD Accuri C6). The data

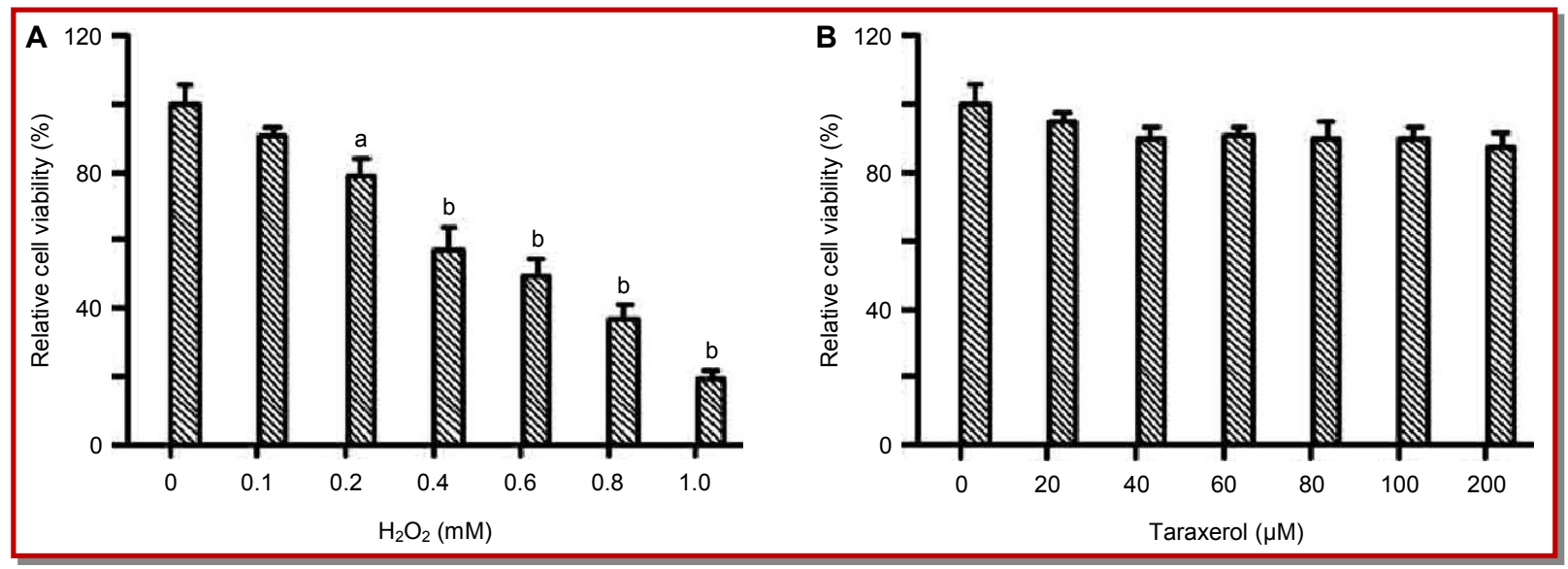

Figure 1: Effects of $\mathrm{H}_{2} \mathrm{O}_{2}$ and taraxerol on the cell viability of L02 cells. $\mathrm{L} 02$ cells were treated with various concentrations of $\mathrm{H}_{2} \mathrm{O}_{2}$ or taraxerol for 12 hours, then measured by MTT analysis. A) Effect of $\mathrm{H}_{2} \mathrm{O}_{2}$ on the cell viability of L02 cells. B) Effect of taraxerol on the cell viability of L02 cells. Data are expressed as mean $\pm S D(n=6) . ~ a p<0.05,{ }^{b} p<0.01$ compared with control were analyzed using BD Accuri C6 Software.

\section{Western blot analysis}

Cells were rinsed twice with ice-cold PBS, and lysed with the RIPA lysis buffer for $30 \mathrm{~min}$ on ice. Lysates were centrifuged $(12,000 \times \mathrm{g})$ at $4^{\circ} \mathrm{C}$ for $15 \mathrm{~min}$. Total cell lysates were separated by SDS-PAGE and transferred to nitrocellulose membranes or polyvinylidene difluoride membranes. Membranes were blocked for 60 min at room temperature. Membranes were probed with specific primary antibodies overnight at $4^{\circ} \mathrm{C}$ and subse-quently incubated with IRDye $800 \mathrm{CW}$ secondary antibodies for 1 hour. Membranes were visualized using Odyssey Infrared Imaging Scanner. The fluorescence intensities were analyzed using Image Studio Software (Li-Cor Biosciences) or membranes were incubated with horseradish peroxidase-conjugated secondary antibodies. Band quantifications were performed by ChemiScope 3400 chemiluminescence imaging systems (Clinx Science Instruments, China).

\section{Statistical analysis}

Results were expressed as mean \pm SD from replicate experiments. Statistical analysis was carried out using an unpaired, two-tailed Student's t-test. Significance was defined as $\mathrm{p}<0.05$ or 0.01 .

\section{Results}

\section{Effect on the cell viability}

The effect of $\mathrm{H}_{2} \mathrm{O}_{2}$ and taraxerol on the viability of L02 cells was evaluated by the MTT assay. Consistent with our previous report, $\mathrm{H}_{2} \mathrm{O}_{2}$ significantly inhibited L02 cell viability (Figure 1A) (Li et al., 2011). However, as shown in Figure 1B, taraxerol alone did not significantly affect the cell viability of L02 cells even at the dose of $200 \mu \mathrm{M}$

Effect on $\mathrm{H}_{2} \mathrm{O}_{2}$-induced cell viability and LDH leakage 


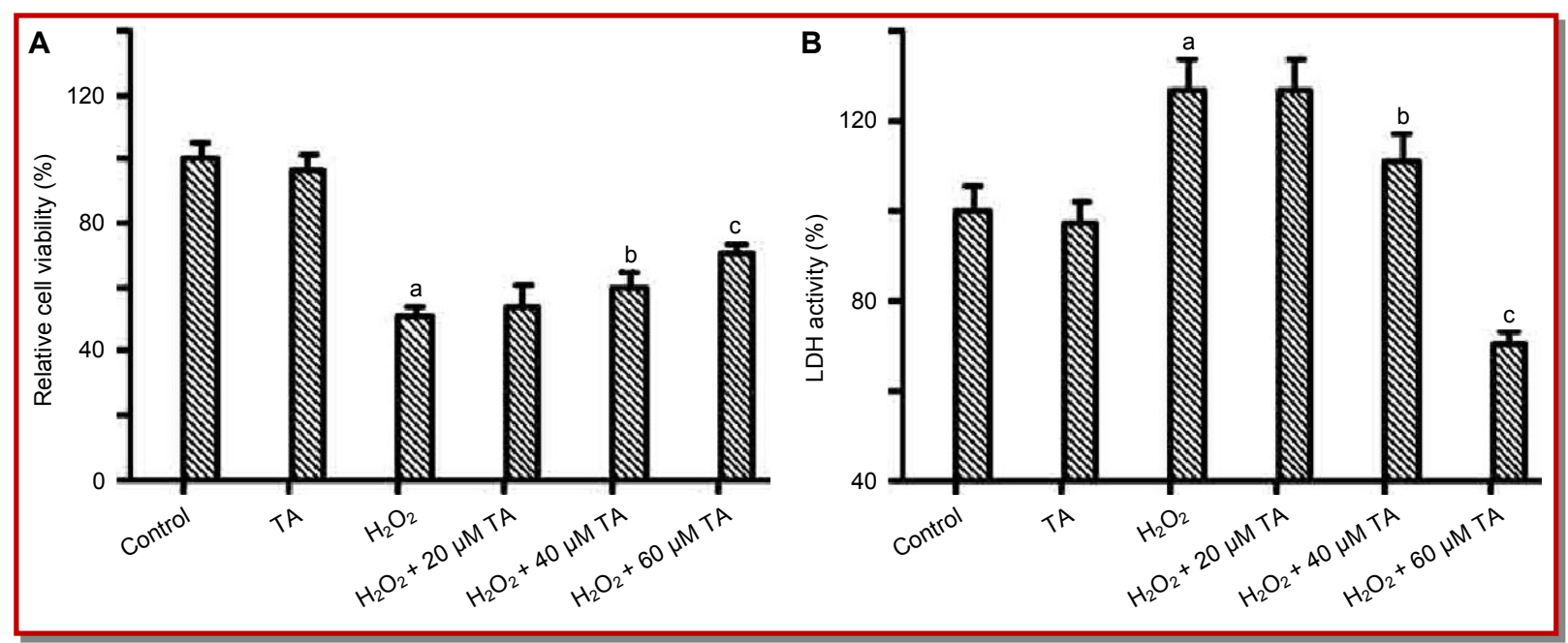

Figure 2: Taraxerol protects L02 cells against $\mathrm{H}_{2} \mathrm{O}_{2}$-induced cell injury. L02 cells were pretreated with or without $40 \mu \mathrm{M}$ taraxerol for 1 hour, followed by $0.4 \mathrm{mM} \mathrm{H}_{2} \mathrm{O}_{2}$ treatment for 12 hours. A) Cell viability was measured by MTT analysis, B) LDH release was measured. TA: taraxerol. Data are expressed as mean $\pm \mathrm{SD}(\mathrm{n}=6)$; ${ }^{\mathrm{p}}<<0.01$ compared with control; $\mathrm{b} p<0.05$, $\mathrm{c} p<0.01$ compared with the group of $\mathrm{H}_{2} \mathrm{O}_{2}$-treated $\mathrm{L} 02$ cells alone

To explore the effect of taraxerol on $\mathrm{H}_{2} \mathrm{O}_{2}$-induced cell viability loss, L02 cells were pretreated with taraxerol at different concentrations for 1 hour, followed by $0.4 \mathrm{mM}$ $\mathrm{H}_{2} \mathrm{O}_{2}$ treatment for 12 hours. As shown in Figure 2A, $\mathrm{H}_{2} \mathrm{O}_{2}$-induced loss of cell viability was significantly decreased by taraxerol in a dose-dependent manner. LDH leakage which was frequently used to evaluate the degree of cellular injury was assayed. $\mathrm{H}_{2} \mathrm{O}_{2}$ stimulation significantly increased LDH leakage in L02 cells (Figure 2B). Taraxerol prevented $\mathrm{H}_{2} \mathrm{O}_{2}$-induced $\mathrm{LDH}$ release.

\section{$\mathrm{H}_{2} \mathrm{O}_{2}$-induced apoptosis}

We further investigated apoptosis of cells by annexin$\mathrm{V} / \mathrm{PI}$ double staining. After being incubated with 40 $\mu \mathrm{M}$ taraxerol for 24 hours, $\mathrm{H}_{2} \mathrm{O}_{2}$ could significantly increase in the early and late stages of apoptotic cells $(12.1,40.1 \%)$ compared with the control group (1.2, $4.3 \%)$ indicating that cells were significantly damaged, while cells treated with taraxerol and $\mathrm{H}_{2} \mathrm{O}_{2}$ were significantly lower in the early and late stages of apoptotic cells $(4.3,22.4 \%)$ than those in the $\mathrm{H}_{2} \mathrm{O}_{2}$ stimulated group (Figure 3 ). These results demonstrated that taraxerol protected $\mathrm{H}_{2} \mathrm{O}_{2}$-induced apoptosis in L02 cells.

\section{Cleavage of caspase-3 and PARP in $\mathrm{H}_{2} \mathrm{O}_{2}$-injured cells}

We examined the expression of cleaved-caspase- 3 and PARP. The results showed that the protein of cleavedcaspase-3 and cleaved-PARP were up-regulated in $\mathrm{H}_{2} \mathrm{O}_{2}$-treated L02 cells, showing that the cells were undergoing apoptosis. However, pretreatment with taraxerol inhibited the increase in the two proteins induced by $\mathrm{H}_{2} \mathrm{O}_{2}$ (Figure 4). These data are in agreement with the results of annexin-V/PI double staining.

\section{Effects on $\mathrm{H}_{2} \mathrm{O}_{2}$-induced $\mathrm{Bcl}-2$ and $\mathrm{Bax}$}

As shown in Figure 5, Bcl-2 protein expression was down-regulated while Bax was up-regulation in $\mathrm{H}_{2} \mathrm{O}_{2}$ treated L02 cells. In contrast, taraxerol could inhibit the expression of $\mathrm{Bax}$ induced by $\mathrm{H}_{2} \mathrm{O}_{2}$, and increased the expression of $\mathrm{Bcl}-2$. Thus, $\mathrm{Bax} / \mathrm{Bcl}-2$ ratio was significantly lower than in $\mathrm{H}_{2} \mathrm{O}_{2}$-treated L02 cells alone.

\section{$\mathrm{H}_{2} \mathrm{O}_{2}$-induced activation of $p 38$ and JNK}

In our previous study, taraxerol markedly repressed LPS-induced p38, ERK and JNK phosphorylation in RAW264.7 cells (Yao et al., 2013). To verify that MAPKs are involved in the apoptosis, cells were pretreated with $30 \mu \mathrm{M}$ inhibitors (U0126, an ERK inhibitor; SB203580, a p38 inhibitor or SP600125, a JNK inhibitor) for 1 hour, followed by addition of $\mathrm{H}_{2} \mathrm{O}_{2}$. As shown in Figure 6A, increase in cleaved-caspase- 3 and cleaved-PARP were prevented by SB203580 and SP600125, while they were no significant change in the U0126-pretreated cells when compared with $\mathrm{H}_{2} \mathrm{O}_{2}$-treated cells alone, indicating that p38 and JNK are involved in $\mathrm{H}_{2} \mathrm{O}_{2}$-induced cell apoptosis in L02 cells.

We further explored whether taraxerol affected the activation of p38 and JNK induced by $\mathrm{H}_{2} \mathrm{O}_{2}$. Cells were treated with $\mathrm{H}_{2} \mathrm{O}_{2}$, JNK and p38 activation increased, while cells were pretreated with taraxerol and $\mathrm{H}_{2} \mathrm{O}_{2}$, p38 and JNK activation reduced in L02 cells compared with the $\mathrm{H}_{2} \mathrm{O}_{2}$-treated group (Figure 6B).

\section{Discussion}

In the present study, we showed that taraxerol dosedependently decreased $\mathrm{H}_{2} \mathrm{O}_{2}$-induced cell viability loss and lactate dehydrogenase $(\mathrm{LDH})$ release. Taraxerol inhibited $\mathrm{H}_{2} \mathrm{O}_{2}$-induced cell apoptosis. Further, taraxerol attenuated $\mathrm{H}_{2} \mathrm{O}_{2}$-induced increase in cleavedcaspase-3 and cleaved-PARP. $\mathrm{H}_{2} \mathrm{O}_{2}$-activated p38 and 


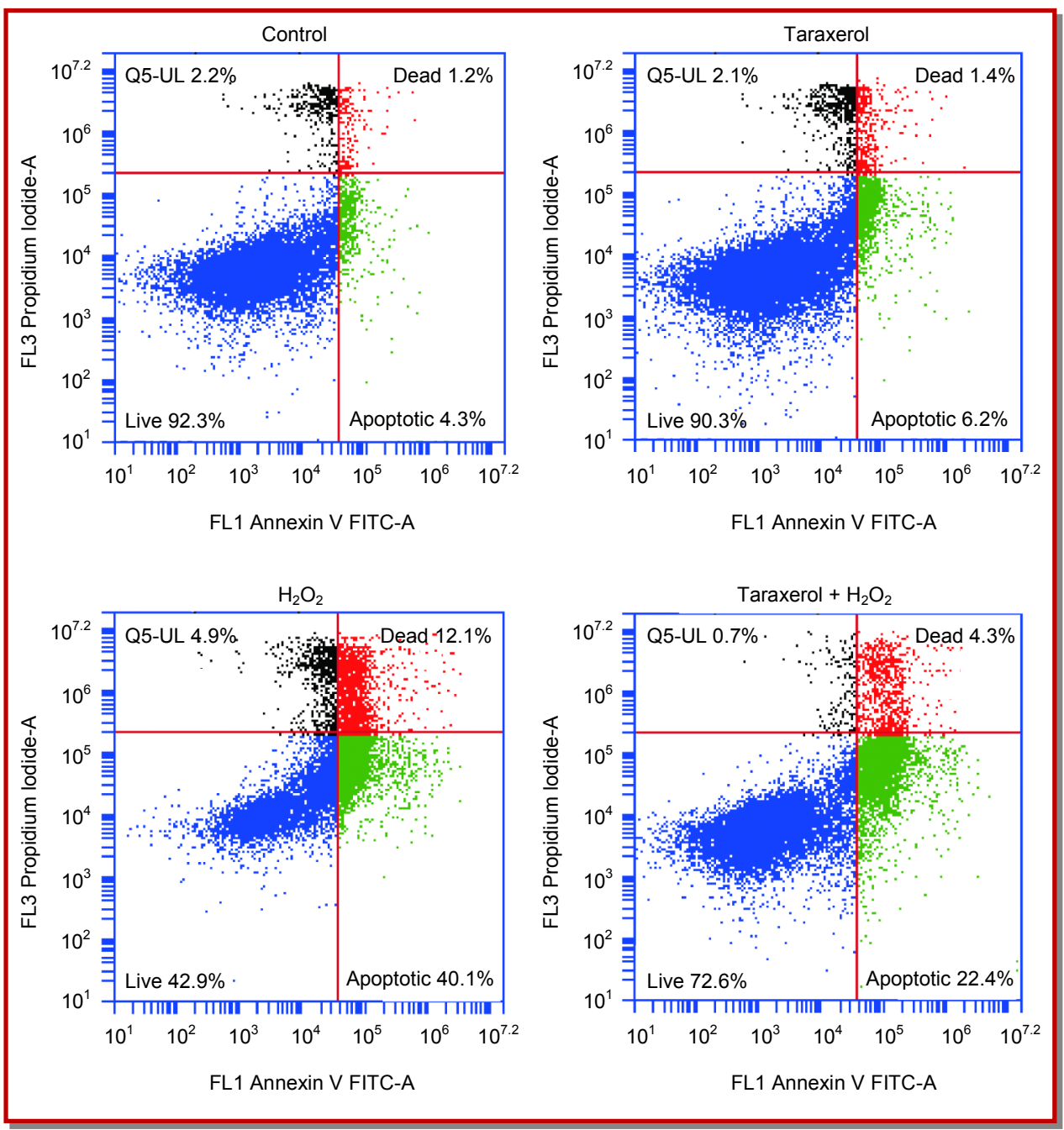

Figure 3: Taraxerol protects L02 cells from $\mathrm{H}_{2} \mathrm{O}_{2}$-induced apoptosis. After treated with taraxerol or $\mathrm{H}_{2} \mathrm{O}_{2}$ for 12 hours, $\mathrm{L} 02$ cells were dyed with both of annexin-V/FITC and propidine iodide (PI). Flow cytometric analysis was performed with BD Accuri C6 Software

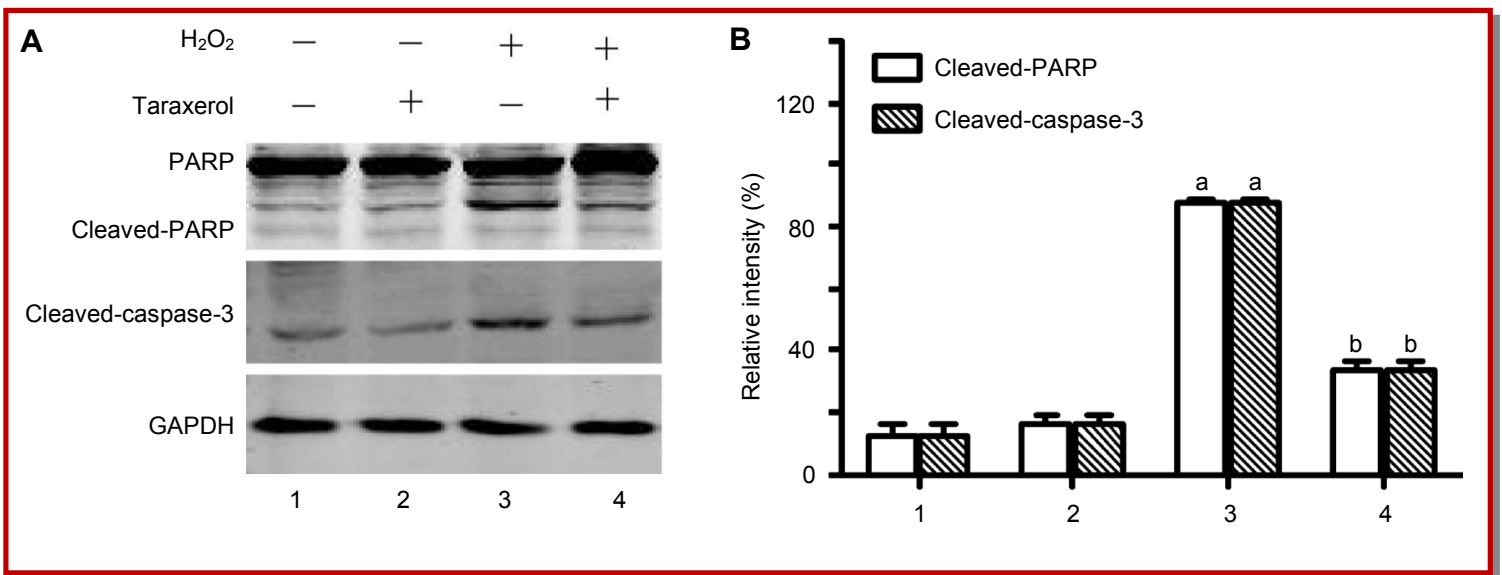

Figure 4: Taraxerol attenuates $\mathrm{H}_{2} \mathrm{O}_{2}$-induced reduction in cleaved-caspase-3 and cleavage of PARP. L02 cells were pretreated with or without $40 \mu \mathrm{M}$ taraxerol for 1 hour, followed by $0.4 \mathrm{mM} \mathrm{H}_{2} \mathrm{O}_{2}$ treatment for 12 hours. A) Then, the expression of cleavedcaspase-3 and PARP was tested by Western blot. GAPDH was used to confirm that equal cell equivalents were loaded. B) Relative intensity of cleaved-caspase- 3 and cleaved-PARP in Figure 4A. Data are expressed as mean \pm SD ( $n=3$ ); ap $<0.01$ compared with control; b ${ }^{\mathrm{p}}<0.01$ compared with the group of $\mathrm{H}_{2} \mathrm{O}_{2}$-treated $\mathrm{L} 02$ cells alone 


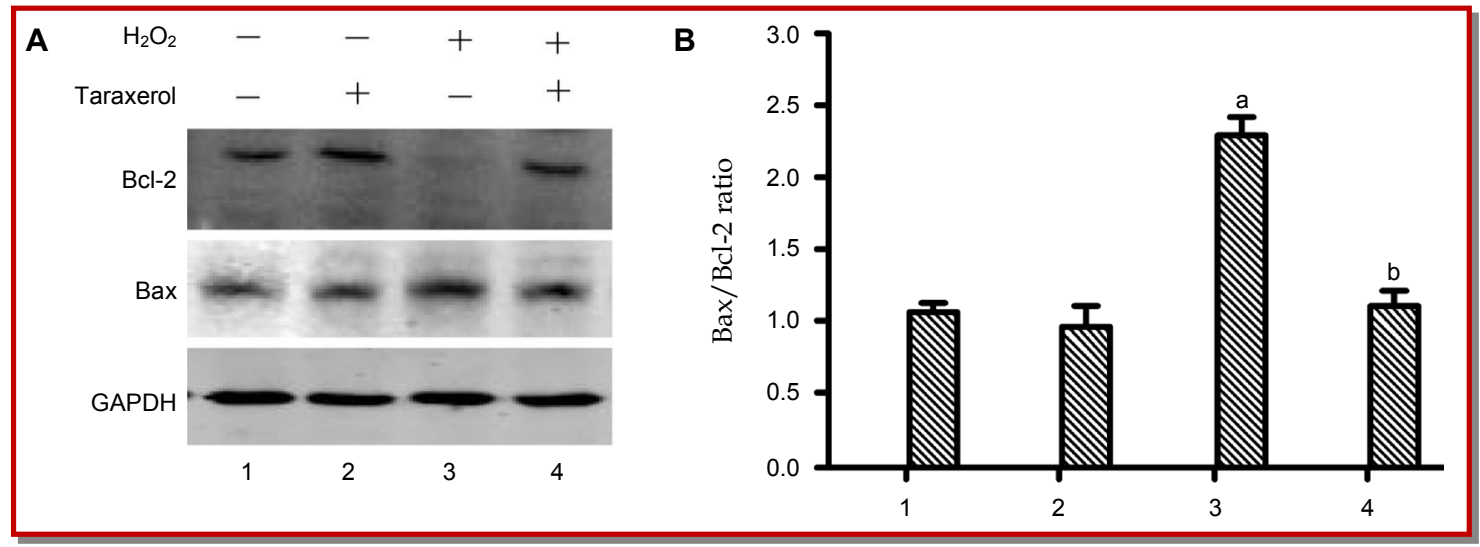

Figure 5: Effects of taraxerol on $\mathrm{H}_{2} \mathrm{O}_{2}$-induced Bcl-2 and Bax. L02 cells were treated with taraxerol or $\mathrm{H}_{2} \mathrm{O}_{2}$ for 12 hours, A) Bcl-2 and Bax were tested by Western blotting. GAPDH was used to confirm that equal cell equivalents were loaded. B) The graph shows the ratio of Bax/Bcl-2 in Figure 5A. Data represent the mean \pm SD ( $n=3)$; a $<<0.01$ compared with control; b $p<0.01$ compared with the group of $\mathrm{H}_{2} \mathrm{O}_{2}$-treated L02 cells alone

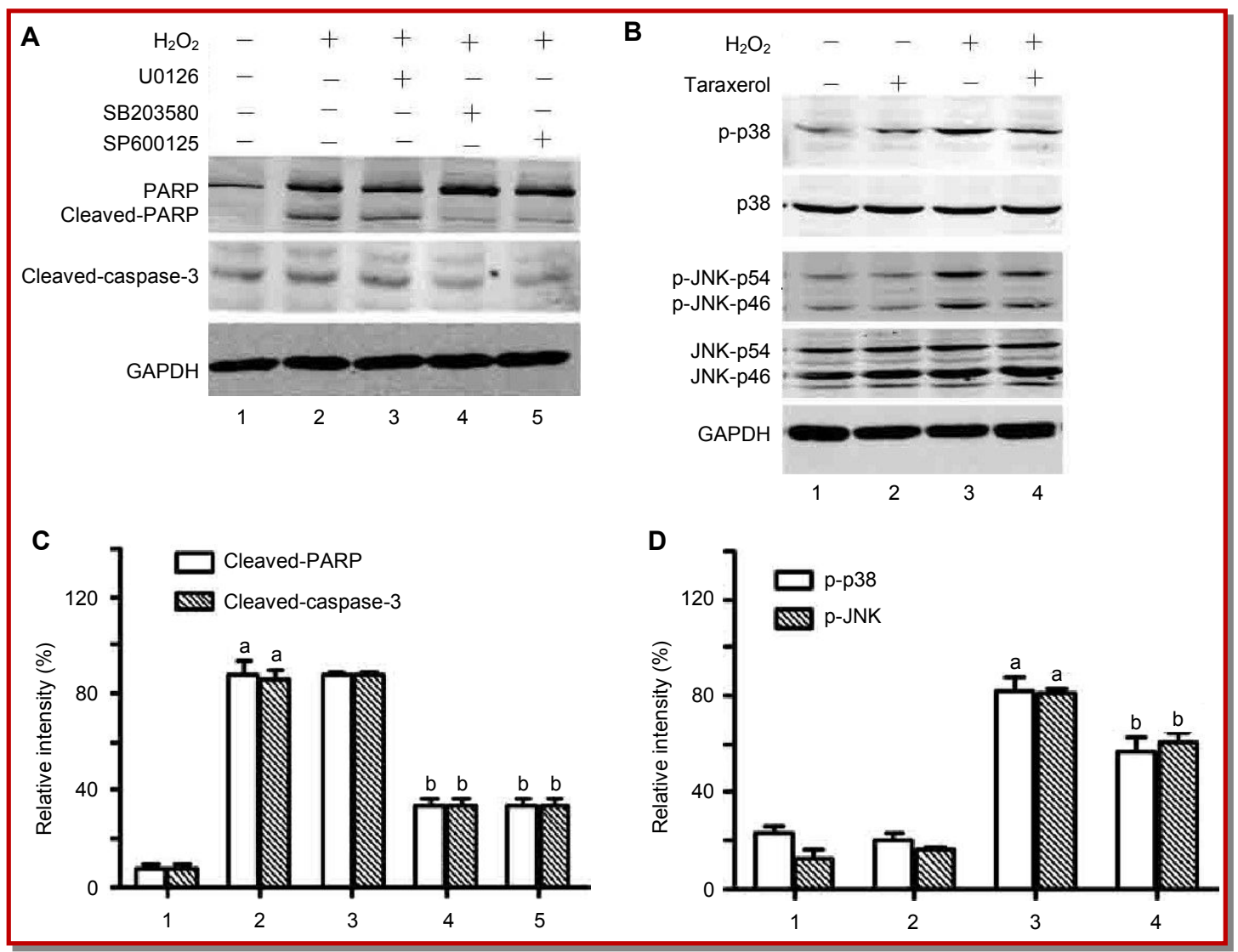

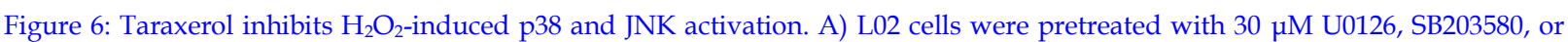
SP600125 for 1 hour, followed by $0.4 \mathrm{mM} \mathrm{H}_{2} \mathrm{O}_{2}$ for 12 hours. The cell lysates were detected by antibodies of cleaved-caspase-3, and PARP. GAPDH was used to confirm that equal cell equivalents were loaded. B) L02 cells were pretreated with or without $40 \mu \mathrm{M}$ taraxerol for 1 hour and then exposed to $0.4 \mathrm{mM} \mathrm{H}_{2} \mathrm{O}_{2}$ for $30 \mathrm{~min}$. The cell lysates were detected by antibodies of p38, phosphop38 (Thr180/Tyr182), JNK/SAPK, and phospho-JNK/SAPK (Thr183/Tyr185). P38 and JNK were used for normalization. GAPDH was used to confirm that equal cell equivalents were loaded. C) Relative intensity of cleaved-caspase-3 and cleaved-PARP in Figure 6A. D) Relative intensity of phospho-p38 and phospho-JNK/SAPK in Figure 6B. Data are expressed as mean \pm SD (n $=3$ ). ap $<0.01$ compared with control; b $\mathrm{p}<0.01$ compared with the group of $\mathrm{H}_{2} \mathrm{O}_{2}$-treated L02 cells alone 
JNK were also inhibited by taraxerol. These data suggest that taraxerol could protect L02 cells against $\mathrm{H}_{2} \mathrm{O}_{2}$-induced apoptosis via suppression of p38 and JNK. Taraxerol might potentially be useful in the preven-tion and treatment of liver diseases.

Bax/Bcl-2 ratio plays an important role in cell apoptosis (Cory and Adams, 2005). Some studies have shown that $\mathrm{H}_{2} \mathrm{O}_{2}$-induced apoptosis is usually related to the ratio of Bax/Bcl-2 (Liu et al., 2013; Huang et al., 2015). In this study, we found that taraxerol significantly inhibited the expression of Bax and promotion of Bcl-2 in L02 cells after $\mathrm{H}_{2} \mathrm{O}_{2}$ stimulation, indicating that taraxerol inhibited $\mathrm{H}_{2} \mathrm{O}_{2}$-induced apoptosis which is associated with decreasing the ratio of Bax/Bcl-2.

It is well known that increased ROS production leads to the activation of ERK, JNK, or p38 (McCubrey et al., 2006). ERK signaling promotes cell survival under mild oxidative stress, whereas JNK and p38 can induce apoptosis by involving direct phosphorylation of pro/ anti-apoptotic Bcl-2 family members, transactivation of transcription factor AP-1, and stabilization of p53 (Groeger et al., 2009). We showed taraxerol protects L02 cells from $\mathrm{H}_{2} \mathrm{O}_{2}$-induced apoptosis by inhibiting JNK and p38. Our previous study demonstrated that Ltheanine could protect $\mathrm{LO} 2$ cells against $\mathrm{H}_{2} \mathrm{O}_{2}$-induced apoptosis via suppression of p38 (Li et al., 2011). However, propofol protects hepatic $\mathrm{L} 02$ cells from $\mathrm{H}_{2} \mathrm{O}_{2}$ -induced apoptosis via activation of ERK pathway (Wang et al., 2008). These data support the view that the MAPK pathway in $\mathrm{H}_{2} \mathrm{O}_{2}$-induced apoptosis is complex. Fisetin, a dietary flavonoid induces apoptosis via modulating the MAPK and PI3K/Akt signalling pathways in human osteosarcoma cells (Li et al., 2015).

Furthermore, hesperidin augmented cellular antioxidant defense capacity through the induction of HO-1 via ERK/Nrf2 signaling (Chen et al., 2010). Hyperoside attenuates $\mathrm{H}_{2} \mathrm{O}_{2}$-induced $\mathrm{L} 02$ cell damage via MAPK (p38 and ERK)-dependent Keap/Nrf2/ARE signaling pathway (Xing et al., 2011). Thus, whether taraxerolstimulated cytoprotective effect is involved in MAPKdependent Keap/Nrf2/ARE signaling pathway remains elusive. On the other hand, Mantzaris reported that iron determines $\mathrm{H}_{2} \mathrm{O}_{2}$-induced apoptotic signaling by sustaining the ASK1/JNK-p38 axis (Mantzaris et al., 2016). Further investigation is needed to identify upstream regulatory proteins such as ASK1 in protective mechanism of taraxerol in $\mathrm{H}_{2} \mathrm{O}_{2}$-induced apoptosis.

\section{Conclusion}

Taraxerol protects human hepatic L02 cells from hydrogen peroxide-induced cell injury including promotion of cell viability, the inhibition of apoptosis and LDH release by the activation of caspases- 3 and PARP, down -regulation of Bax/Bcl-2 ratio. It inhibits p38 and JNK signal pathway activated by $\mathrm{H}_{2} \mathrm{O}_{2}$. Taraxerol may be an effectively protective agent against oxidative stressinduced liver injury.

\section{Acknowledgement}

This work was supported by the Major Program of the Natural Science Foundation of the Anhui Higher Education Institutions of China (No. KJ2014A149) and Natural Science Foundation of Bengbu University (No. 2011ZR02zd).

\section{Conflict of Interest}

All authors have completed the ICMJE uniform disclosure form and declare no support from any organization for the submitted work.

\section{References}

Brewer TF, Garcia FJ, Onak CS, Carroll KS, Chang CJ. Chemical approaches to discovery and study of sources and targets of hydrogen peroxide redox signaling through NADPH oxidase proteins. Annu Rev Biochem. 2015; 84: 76590.

Chen MC, Ye YY, Ji G, Liu JW. Hesperidin upregulates heme oxygenase-1 to attenuate hydrogen peroxide-induced cell damage in hepatic L02 cells. J Agric Food Chem. 2010; 58: 3330-35.

Cory S, Adams JM. Killing cancer cells by flipping the Bcl-2/ Bax switch. Cancer Cell. 2005; 8: 5-6.

Gough DR, Cotter TG. Hydrogen peroxide: A Jekyll and Hyde signalling molecule. Cell Death Dis. 2011; 2: e213.

Groeger G, Quiney C, Cotter TG. Hydrogen peroxide as a cellsurvival signaling molecule. Antioxid Redox Signal. 2009; 11: 2655-71.

Guicciardi ME, Gores GJ. Apoptosis as a mechanism for liver disease progression. Semin Liver Dis. 2010; 30: 402-10.

Huang C, Lin Y, Su H, Ye D. Forsythiaside protects against hydrogen peroxide-induced oxidative stress and apoptosis in PC12 cell. Neurochem Res. 2015; 40: 27-35.

Jang DS, Cuendet M, Pawlus AD, Kardono LB, Kawanishi K, Farnsworth NR, Fong HH, Pezzuto JM, Kinghorn AD. Potential cancer chemopreventive constituents of the leaves of Macaranga triloba. Phytochemistry 2004; 65: 345-50.

Li G, Kang J, Yao X, Xin Y, Wang Q, Ye Y, Luo L, Yin Z. The component of green tea, L-theanine protects human hepatic L02 cells from hydrogen peroxide-induced apoptosis. Eur Food Res Technol. 2011; 233: 427-35.

Li J, Li W, Huang M, Zhang X. Fisetin, a dietary flavonoid induces apoptosis via modulating the MAPK and PI3K/Akt signalling pathways in human osteosarcoma (U-2 OS) cells. Bangladesh J Pharmacol. 2015; 10: 820-29.

Liu Y, E Q, Zuo J, Tao Y, Liu W. Protective effect of cordyceps polysaccharide on hydrogen peroxide-induced mitochondrial dysfunction in HL-7702 cells. Mol Med Rep. 2013; 7: 747 
$-54$

Mantzaris MD, Bellou S, Skiada V, Kitsati N, Fotsis T, Galaris D. Intracellular labile iron determines $\mathrm{H} 2 \mathrm{O} 2$-induced apoptotic signaling via sustained activation of ASK1/JNK-p38 axis. Free Radic Biol Med. 2016; 97: 454-65.

McCubrey JA, Lahair MM, Franklin RA. Reactive oxygen species-induced activation of the MAP kinase signaling pathways. Antioxid Redox Signal. 2006; 8: 1775-89.

Sangeetha KN, Shilpa K, Jyothi Kumari P, Lakshmi BS. Reversal of dexamethasone induced insulin resistance in 3T3L1 adipocytes by 3beta-taraxerol of Mangifera indica. Phytomedicine 2013; 20: 213-20.

Sangeetha KN, Sujatha S, Muthusamy VS, Anand S, Nithya N, Velmurugan D, Balakrishnan A, Lakshmi BS. 3beta-taraxerol of Mangifera indica, a PI3K dependent dual activator of glucose transport and glycogen synthesis in 3T3-L1 adipocytes. Biochim Biophys Acta. 2010; 1800: 359-66.

Setzer WN, Shen X, Bates RB, Burns JR, McClure KJ, Zhang P, Moriarity DM, Lawton RO. A phytochemical investigation of Alchornea latifolia. Fitoterapia 2000; 71: 195-98.

Sharma K, Zafar R. Occurrence of taraxerol and taraxasterol in medicinal plants. Pharmacogn Rev. 2015; 9: 19-23.

Takasaki M, Konoshima T, Tokuda H, Masuda K, Arai Y, Shiojima K, Ageta H. Anti-carcinogenic activity of taraxacum plant. II. Biol Pharm Bull. 1999; 22: 606-10.

Tsao CC, Shen YC, Su CR, Li CY, Liou MJ, Dung NX, Wu TS. New diterpenoids and the bioactivity of Erythrophleum fordii. Bioorg Med Chem. 2008; 16: 9867-70.

Veal E, Day A. Hydrogen peroxide as a signaling molecule. Antioxid Redox Signal. 2011; 15: 147-51.

Wang H, Xue Z, Wang Q, Feng X, Shen Z. Propofol protects hepatic L02 cells from hydrogen peroxide-induced apoptosis via activation of extracellular signal-regulated kinases pathway. Anesth Analg. 2008; 107: 534-40.

Xing HY, Liu Y, Chen JH, Sun FJ, Shi HQ, Xia PY. Hyperoside attenuates hydrogen peroxide-induced L02 cell damage via MAPK-dependent Keap(1)-Nrf(2)-ARE signaling pathway. Biochem Bioph Res Co. 2011; 410: 759-65.

Yao X, Li G, Bai Q, Xu H, Lü C. Taraxerol inhibits LPS-induced inflammatory responses through suppression of TAK1 and Akt activation. Int Immunopharmacol. 2013; 15: 316-24. 


\section{Your feedback about this paper}

1. Number of times you have read this paper 0

2. Quality of paper Click

3. Your comments 